

entimos um imenso orgulho e também a tremenda responsabilidade de dirigirmos a RAE-revista de administração de empresas no ano em que este prestigiado periódico acadêmico completa seu quinquagésimo aniversário. Apoiada em ombros gigantes, a atual equipe da $R A E$ esmera-se para prestar uma modesta contribuição para a história desta instituição de meio século e convida toda a comunidade científica para celebrar este aniversário.

A $R A E$ é o periódico com maior tempo de publicação ininterrupta do Brasil na área de Administração, e não são muitos os periódicos que já atingiram esta marca, em outros países ou áreas do conhecimento. Esta longevidade representa tradição, reconhecimento, capacidade de renovação e consolidação de um relevante canal de expressão para a comunidade acadêmica brasileira.

Dezenas de editores, centenas de profissionais na equipe da redação, milhares de colaboradores, entre autores e avaliadores, e um número incontável de leitores ajudaram a construir a $R A E \mathrm{em}$ seus 50 anos de publicação relevante e de grande influência na área de Administração no país. Sintonizada com as demandas da academia e sempre inovadora, a RAE não se acomoda em apenas incensar o seu passado, mas também olha para o futuro procurando novos caminhos para ampliar o seu impacto para além das fronteiras brasileiras e explorando novas mídias.

O crescente protagonismo do Brasil no cenário internacional exige que a $R A E$ leve a sua liderança consolidada no campo das publicações científicas brasileiras para outras regiões do planeta. No século XXI, a $R A E$ deverá tornar-se um importante ca- nal de expressão para a academia latinoamericana e dos países em desenvolvimento, com capacidade de influenciar os mais importantes centros criadores de conhecimento. A RAE sempre pautou as discussões mais candentes no campo da Administração e Negócios e vai continuar a fazê-lo para uma audiência cada vez maior, seja por meio de canais de comunicação mais tradicionais ou mais inovadores.

Abrimos esta edição comemorativa com uma mensagem do professor Carlos Osmar Bertero, duas vezes diretor da $R A E$, sobre a relevância da $R A E$ no cenário nacional. Dois artigos apresentam a evolução de áreas importantes do campo da Administração, como Recursos Humanos e Logística, este último escrito pelo professor Claude Machline, que também foi autor na primeira $R A E$, em 1961.

Dois artigos críticos são apresentados a seguir, o primeiro argumentando sobre as origens e consequências do produtivismo a que estão submetidos os pesquisadores brasileiros e outro discutindo causas e efeitos do domínio anglófono na academia. Os dois artigos que fecham a edição apresentam uma avaliação da relevância da $R A E$ em seus 50 anos de história. O primeiro usa a $R A E$ como estudo de caso para analisar as transformações das publicações acadêmicas nas últimas cinco décadas e o segundo apresenta um estudo bibliométrico sobre o acervo da RAE-eletrônica entre 2002 e 2010.

Parabéns à $R A E$ por seus 50 anos profícuos e, a todos, uma boa leitura!

\section{Equipe RAE-publicações}

